Summerfield but not Veale. And so, what lies at the heart of this debate is the balance between the extreme individualism seen in the expansion of CBT on this scale and broader ideas about citizenship that take a more complex approach to the place of individual happiness in the world. ${ }^{5}$ Will Layard's vision be counterproductive across society? Clearly we shall have to wait and see.

Michael King, MD, PhD, Department of Mental Health Sciences, Royal Free and University College Medical School, Hampstead Campus, Rowland Hill Street, London NW3 2PF, UK. Email: m.king@medsch.ucl.ac.uk

References

1 Browning DS, Evison IS. Does Psychiatry Need a Public Philosophy? Nelson Hall, 1991.

2 Porter R. Enlightenment: Britain and the Creation of the Modern World. Penguin, 2000.

3 Smith A. Theory of Modern Sentiments. A Millar, 1759.

4 Tjeltveit AC. Ethics and Values in Psychotherapy. Routledge, 1999.

5 Bellah RN. The Good Society. Knopf, 1999.

\section{psychiatry in pictures}

\title{
Alexandra Reinhardt 1960-2004. River and Red Butterfly
}

Text by Dr Alexandra Pitman

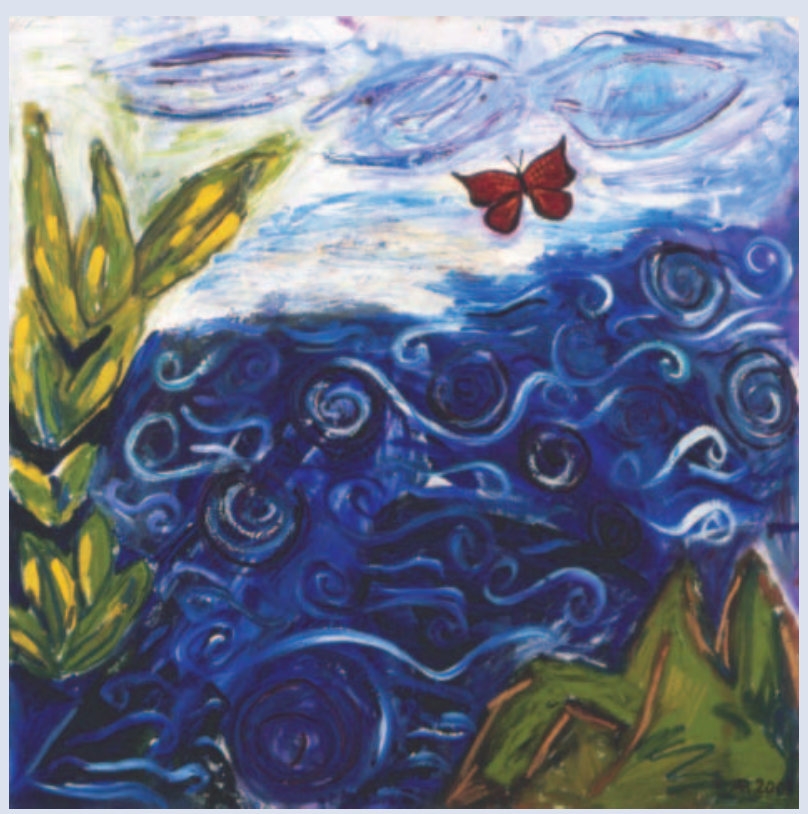

Diagnosed with Diamond-Blackfan anaemia and congenital deafness as an infant and sentenced to years of transfusions, admissions and medications, the artist Alexandra Reinhardt initially used art as a form of therapy. During the long hours of transfusions she would vent her frustration by making collages out of the equipment used: giving sets, syringes and blood transfusion bags. In her twenties she was the first deaf student at the Chelsea College of Art and continued to use the visual arts and poetry as a means of expressing the impact of her condition.

Her lifelong relationship with hospitals intensified as her illness worsened and at the age of 32 she was diagnosed with depression. What is striking about her later work is the lack of any correlation between her clinical state and the mood of her work. When her body was at its weakest, her paintings changed to express a positive energy and vibrancy at odds with her extreme frailty, as shown in the image chosen here.

Following her death from septicaemia at the age of 43 her family established a scheme in her name, designed to bring art and creative activity into hospitals. This reflected her wish to create more uplifting environments in hospitals for patients, relatives and staff. The catalogue of her own work reflects the depths of her suffering as well as her humour, vitality and force of personality. For patients on psychiatric or any other wards the question of whether art in hospitals should be joyful to be truly uplifting remains a subject for debate.

The Alexandra Reinhardt Memorial Award is a $£ 10000$ annual prize awarded by Paintings in Hospitals and funded by the Max Reinhardt Charitable Trust. The winning artist works on a programme of creative activities with patients, staff and visitors in a National Health Service hospital and is commissioned to create a major work of art for permanent display at that site. In addition a further piece is produced for the Paintings in Hospitals Collection which will be available to borrow by other hospitals in the UK. For further information please contact Helen Bonar at Paintings in Hospitals +44 (0)207 407 3222; mail@paintingsinhospitals.org.uk; www.paintingsinhospitals.org.uk. More information about Alexandra can be found at www.alexandrareinhardt.org.uk 